\title{
Formation and characteristics of ions and charged aerosol particles in a native Australian Eucalypt forest
}

\author{
T. Suni ${ }^{1}$, M. Kulmala ${ }^{1}$, A. Hirsikko ${ }^{1}$, T. Bergman ${ }^{2}$, L. Laakso ${ }^{1}$, P. P. Aalto ${ }^{1}$, R. Leuning ${ }^{3}$, H. Cleugh ${ }^{3}$, S. Zegelin $^{3}$, \\ D. Hughes ${ }^{3}$, E. van Gorsel ${ }^{3}$, M. Kitchen ${ }^{3}$, M. Vana ${ }^{4}$, U. Hõrrak ${ }^{4}$, S. Mirme ${ }^{4}$, A. Mirme ${ }^{4}$, S. Sevanto ${ }^{1}$, J. Twining ${ }^{5}$, and \\ C. Tadros $^{5}$ \\ ${ }^{1}$ Department of Physical Sciences, P.O.Box 64, FIN-00014 University of Helsinki, Finland \\ ${ }^{2}$ Center for High-Performance Computing and Networking CSC, PO. BOX 405, 02101 Espoo, Finland \\ ${ }^{3}$ CSIRO Marine and Atmospheric Research, GPO Box 1666, Canberra ACT 2601, Australia \\ ${ }^{4}$ Institute of Physics, University of Tartu, Ülikooli Str 18., EE2400 Tartu, Estonia \\ ${ }^{5}$ Institute for Environmental Research, ANSTO, PMB 1, Menai NSW 2234, Australia
}

Received: 15 June 2007 - Published in Atmos. Chem. Phys. Discuss.: 18 July 2007

Revised: 30 October 2007 - Accepted: 5 December 2007 - Published: 14 January 2008

\begin{abstract}
Biogenic aerosol formation is likely to contribute significantly to the global aerosol load. In recent years, newparticle formation has been observed in various ecosystems around the world but hardly any measurements have taken place in the terrestrial Southern Hemisphere. Here, we report the first results of atmospheric ion and charged particle concentrations as well as of new-particle formation in a Eucalypt forest in Tumbarumba, South-East Australia, from July 2005 to October 2006. The measurements were carried out with an Air Ion Spectrometer (AIS) with a size range from 0.34 to $40 \mathrm{~nm}$. The Eucalypt forest was a very strong source of new aerosol particles. Daytime aerosol formation took place on $52 \%$ of days with acceptable data, which is 2-3 times as often as in the Nordic boreal zone. Average growth rates for negative/positive $1.5-3 \mathrm{~nm}$ particles during these formation events were $2.89 / 2.68 \mathrm{nmh}^{-1}$, respectively; for 3-7 nm particles $4.26 / 4.03$, and for 7-20 nm particles $8.90 / 7.58 \mathrm{nmh}^{-1}$, respectively. The growth rates for large ions were highest when the air was coming from the native forest which suggests that the Eucalypts were a strong source of condensable vapours. Average concentrations of cluster ions $(0.34-1.8 \mathrm{~nm})$ were $2400 / 1700 \mathrm{~cm}^{-3}$ for negative/positive ions, very high compared to most other measurements around the world. One reason behind these high concentrations could be the strong radon efflux from the soils around the Tumbarumba field site. Furthermore, comparison between night-time and daytime concentrations supported the view that cluster ions are produced close to the surface within the boundary layer also at night but that large ions are mostly produced in daytime. Finally, a previously unreported phenomenon, nocturnal aerosol formation, appeared
\end{abstract}

Correspondence to: T. Suni

(tanja.suni@helsinki.fi) in $32 \%$ of the analysed nights but was clustered almost entirely within six months from summer to autumn in 2006. From January to May, nocturnal formation was 2.5 times as frequent as daytime formation. Therefore, it appears that in summer and autumn, nocturnal production was the major mechanism for aerosol formation in Tumbarumba.

\section{Introduction}

The influence of aerosol particles on climate is the largest uncertainty in current climate models. Aerosols are produced by human activity but they are also formed naturally in oceans, deserts, and forests. Trees, in particular, are efficient emitters of volatile organic compounds (VOC) such as terpenes that react with atmospheric oxidants and form less volatile organic vapours that condense on freshly nucleated nanometre-sized particles. Observations made during the last decade or so demonstrate clearly that production of new aerosol particles by nucleation and subsequent growth by condensation of organic vapours is a frequent phenomenon that takes place in most atmospheric environments (e.g. Kulmala et al., 2004). Later analyses have shown that this phenomenon is capable of affecting particle number concentrations even at global scales (Spracklen et al., 2006). At regional scales, atmospheric aerosol formation is likely to affect the population of $\mathrm{CCN}$ (cloud condensation nuclei) particles influencing cloud properties and thereby climate (Kerminen et al., 2005; Laaksonen et al., 2005). Determining the magnitude and driving factors of biogenic aerosol production in different ecosystems is crucial for future development of climate models.

Published by Copernicus Publications on behalf of the European Geosciences Union. 


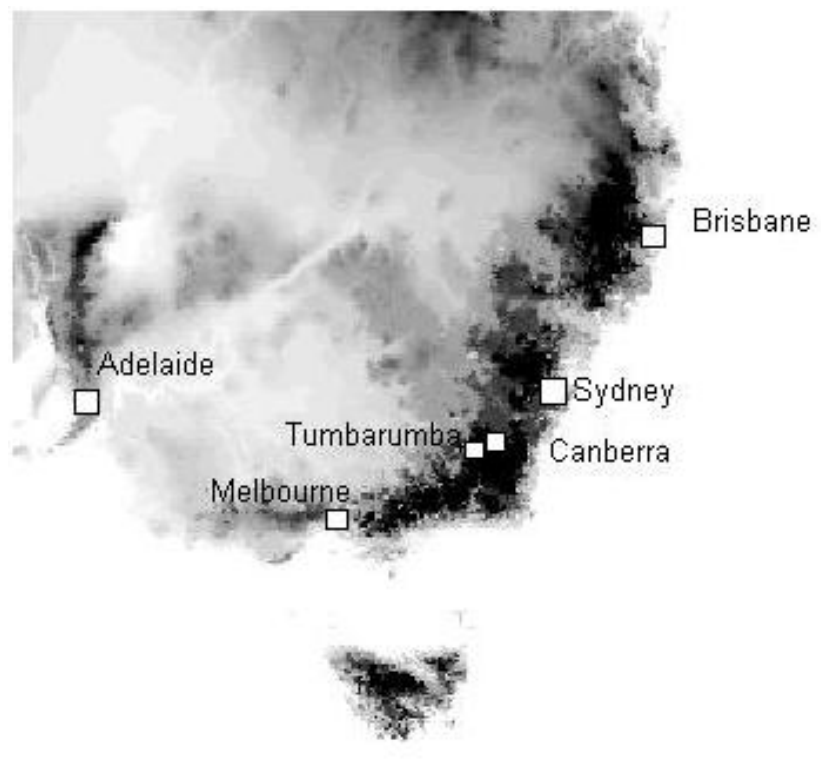

Fig. 1. Elevation map of South-East Australia. The white squares show the location of the major cities and of the Tumbarumba flux station.

Air ions exist everywhere in the Earth's atmosphere (e.g. Israël, 1970; Arnold et al., 1977; Hõrrak, 2001; Eichkorn et al., 2002; Lee et al., 2003). They participate in different atmospheric processes such as cloud dynamics and precipitation (Pruppacher and Klett, 1997; Laakso et al., 2003; Andronache et al., 2006). Through ion-mediated nucleation, ions act also as one pathway to new aerosol particle formation (e.g. Yu and Turco, 2001). The role of ions in atmospheric aerosol formation has remained a controversial topic (Hõrrak et al., 1998; Tammet et al., 1988; Turco et al., 1998; Yu and Turco, 2001; Laakso et al., 2002, 2007; Lee et al., 2003; Kazil and Lovejoy, 2004; Lovejoy et al., 2004; Eisele et al., 2006; Kanawade and Tripathi, 2006; Yu, 2006). Some of the studies made so far suggest that the contribution of ion-induced nucleation to the total nucleation rate is dominant (Yu and Turco, 2001; Yu, 2006) whereas other studies indicate that the role of ions in aerosol formation is about $10 \%$ or less (Laakso et al., 2007; Eisele et al., 2006).

So far, most studies of aerosol production in land ecosystems have taken place at continental and coastal sites in the Northern Hemisphere (Kulmala et al., 2004). In or near Australia, earlier studies on ultrafine aerosol particles have focussed mainly on biomass burning (Keywood et al., 2000; Gras et al., 1999; Generoso et al., 2003) and processes in the coastal or marine boundary layer or in the middle or free troposphere (Johnson et al., 2005; Gras, 1991; Bates et al., 2000; Zaizen et al., 1996). In the largely uninhabited continental Australia, studies of biogenic aerosol production have been very scarce. Simoneit et al. (1991) compared extractable organic matter in $>300 \mathrm{~nm}$ particles in South-East
Australia and coastal New Zealand and demonstrated that the aerosols were mainly biogenic. They also found a reasonable fit between the aerosol and local plant extract. Later, Thomas et al. $(2008)^{1}$ observed nucleation-mode particles $(>8 \mathrm{~nm})$ at three sites ranging from semi-urban to remote in tropical Northern Territory over $2-5$ days in July 1998 . Jimi et al. (2003) determined that the observed diurnal variation in nano-particle concentrations at the Cape Grim meteorological station on the northwest coast of Tasmania was linked to air masses from continental Australia, yielding daytime peak concentrations consistent with secondary aerosol production by photochemical processes.

Australia is a vast island continent the size of Europe in the Southern Hemisphere. It is home to more than $500 \mathrm{Eu}-$ calypt species with so far unknown aerosol-forming potential. In the present paper we describe the first air ion measurements in an evergreen Eucalypt forest in Tumbarumba, New South Wales (NSW). We focus on new-particle formation events, their frequency and seasonal variation, and on the size-dependent growth rates of the particles during these formation events. We study also the effect of meteorological variables on new-particle formation. This study is a step towards determining the contribution of forests to the global aerosol load.

\section{Materials and methods}

\subsection{Site and station description}

The Tumbarumba flux station is located in the Bago State forest in south-eastern New South Wales, about $100 \mathrm{~km}$ west from Canberra, at $35^{\circ} 39^{\prime} 20.6^{\prime \prime} \mathrm{S} 148^{\circ} 09^{\prime} 07.5^{\prime \prime} \mathrm{E}$ (Fig. 1). The dominant species in this tall open Eucalypt forest are E. delegatensis (Alpine Ash) and E. dalrympleana (Mountain Gum) with average tree height of $40 \mathrm{~m}$. The elevation of the site is $1200 \mathrm{~m}$ and the mean annual precipitation $1500 \mathrm{~mm}$ with considerable inter- and intra-annual variation. The 48400 ha of native forest have been managed for wood production for over 100 years. The instrument mast is $70 \mathrm{~m}$ tall. Measurements above the canopy include temperature, humidity, wind speed, wind direction, rainfall, incoming and reflected shortwave radiation, net radiation, and eddy covariance measurements of $\mathrm{CO}_{2}$ and water-vapour fluxes (Leuning et al., 2005).

\subsection{Aerosol measurements}

The total concentration of ultrafine aerosol particles (lower detection limit $\sim 14 \mathrm{~nm}$ ) was measured with a condensational particle counter (CPC), TSI model 3010, at the height of

\footnotetext{
${ }^{1}$ Thomas, S., Morawska, L., Akber, R., Quintarelli, F., Martin P., Ryan, B., Keogh, D. U.: The source and behaviour of submicrometre airborne particles at a site in remote Northern Australia, in preparation, 2008.
} 

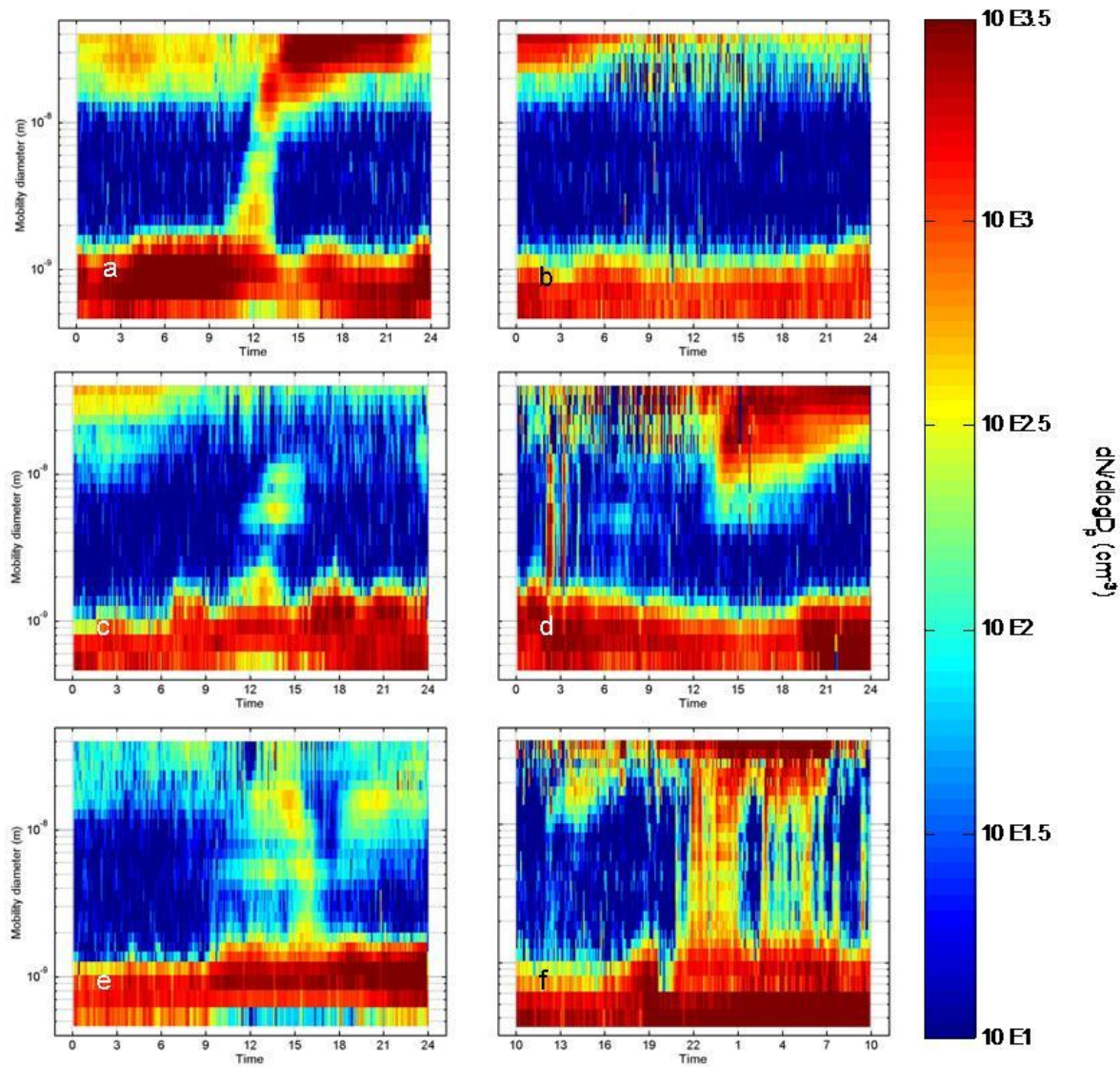

Fig. 2. Classification of new particle formation in Tumbarumba: (a) normal with typical banana-shaped growth pattern, (b) non-event, (c) interrupted, (d) Aitken, (e) unclear, and (f) nocturnal (see 2.2 for explanation). Notice the different time axis for (f). At the bottom of each size distribution plot is the band of cluster ions $(0.34-1.8 \mathrm{~nm})$. At the top ( 25 to $40 \mathrm{~nm})$ is the start of the Aitken mode. Particles between these two modes are called intermediate. Colour indicates the number concentration of particles.

$70 \mathrm{~m}$ on the tower in a box housing the pump, the CPC, the butanol bottle, tubing, and electronics.

We detected new-particle formation by measuring size distributions of air ions (naturally charged clusters and aerosol particles) from July 2005 to October 2006 with an Air Ion Spectrometer (AIS). The AIS (Airel Ltd., Estonia) measures the mobility distribution of both negative and positive air ions in the range of 2.4 to $0.0075 \mathrm{~cm}^{2} \mathrm{~V}^{-1} \mathrm{~s}^{-1}$. This corresponds to a diameter range of approximately $0.34 \mathrm{~nm}$ to $40 \mathrm{~nm}$, that is, from cluster ions $(0.34$ to $1.8 \mathrm{~nm}$ ) to intermediate ( 1.8 to $7.5 \mathrm{~nm})$ and to large ions $(15-40 \mathrm{~nm})$. The largest observed ions form part of the Aitken mode (25-100 nm).

The AIS consists of two cylindrical aspiration-type Differential Mobility Analysers (DMA), one for positive and one for negative ions. Each mobility analyser has 21 collector electrodes provided with individual electrometrical amplifiers for measuring the electrical current carried by ions of different mobilities (Mirme et al. 2007). The AIS was located in a shed on the ground next to the instrument tower. The copper inlet tube (id $5 \mathrm{~cm}$, length $60 \mathrm{~cm}$ ) was led through the wall at approximately $1.5 \mathrm{~m}$ height.
After filtering out days when measurement breaks prevented unambiguous event determination, we classified newparticle formation visually as follows (Fig. 2): normal - formation started from cluster ions and continued to Aitken mode with the growing intermediate ions forming the familiar banana-shaped surface plot (Dal Maso et al., 2005); interrupted - formation started from cluster ions but did not reach Aitken mode; Aitken - formation started from intermediate or large ions and took place mainly in the Aitken mode; non-event - no growth was observable in the cluster or Aitken modes and no intermediate ions appeared during the day; unclear - days that did not fit into any of the previous three daytime categories, usually featuring irregular or stationary, neither increasing nor decreasing concentrations of intermediate ions. Finally, nocturnal - sudden, mostly nocturnal appearance of large quantities of ions usually in all size classes but always at least in the intermediate ions. The ion burst was so sudden that any banana-type, time-dependent growth was impossible to discern with the naked eye except rarely in the largest, Aitken-mode ions.

Because visual analysis is always subjective, three 


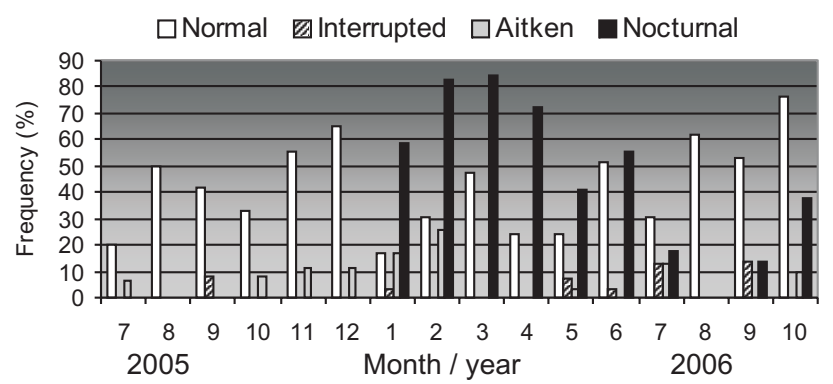

Fig. 3. Frequency of daytime and night-time formation events during July 2005-October 2006; event classification as in Fig. 2.

different people classified the events independently at first and then worked on the analysis until they reached consensus. The analysis followed roughly the guidelines presented in Dal Maso et al. (2005) for neutral and charged particles from 3 to about $700 \mathrm{~nm}$ in diameter measured in Hyytiälä, southern Finland.

Because of the small number of non-event days in Tumbarumba (Table 1), when analysing the effect of meteorological variables on aerosol formation we compared days with a normal event (148) with the sum of non-event (21) and unclear (145) days. On the one hand, adding the unclear days decreased the difference in meteorological variables between the two classes but on the other hand it gave a more realistic picture of aerosol dynamics in Tumbarumba where aerosol activity is much higher than in Hyytiälä or elsewhere in the boreal zone (Dal Maso et al., 2005, 2007).

\section{Results and discussion}

\subsection{New-particle formation events}

\subsubsection{Event types and seasonal variation}

A typical normal banana-type formation event (Fig. 2a) occurred on $42 \%$ of the observed days (Table 1). These events usually started between 08:00 and 10:00 and continued to 15:00-24:00. They appeared to have a peak from late winter to early summer (August to December) and a minimum from mid-summer to autumn (January-May, Fig. 3, Table 1) but these patterns were not entirely consistent, as more events occurred in March 2006 than in October 2005. Winter did not exhibit a clear pattern of new-particle formation as the first winter month, June 2006, produced a lot of formation events but the surrounding months, May and July, did not (Fig. 3). Unclear days were practically as frequent (41\%) as the normal event days, and only $6 \%$ of the observed days were non-events, that is, they contained no clear change in the size distribution of ions and charged aerosol particles.

The amount of unclear days in Tumbarumba was within the range observed at four stations in the Nordic boreal zone but the ratio of banana-type events to non-events on the re- maining days was much higher, 7.0, compared to the 0.41.2 in the North (Dal Maso et al., 2007). Taking into account the interrupted and Aitken events, a daytime formation event took place on $52 \%$ of the days with acceptable data (Table 1). This is 1.9 to 3.4 times as often as in the North (Dal Maso et al., 2007). The cold and dark winter in the boreal zone reduces the amount of condensable vapours and necessary photochemistry and is one very likely reason for this difference. Another one could be the particularly clean air in Tumbarumba (see 3.2.1.). Accumulation-mode particles $(100-1000 \mathrm{~mm})$ scavenge freshly nucleated particles effectively (coagulation sink) and also form a large surface for the condensation of organic vapours (condensation sink). In clean air, the organic vapours are available for condensational growth of the freshly nucleated particles.

During summer, autumn, and early winter (January-June), we observed a previously unreported phenomenon, nocturnal aerosol formation (Fig. 2f), where large numbers of ions appeared in most size classes at the same time during the night. Unlike daytime events, these nocturnal events had a clear seasonal pattern: they emerged for the first time in January 2006 and continued strongly until June (Fig. 3, Table 1). They reappeared in much weaker form in July, September, and October. We were able to exclude instrument malfunction as a potential cause because an SMPS observed the same phenomenon during a 5-week campaign in May-June 2006 (not shown).

Strong nocturnal formation took place in $32 \%$ of the analysed nights and almost all of these events were clustered within six months from January to June 2006. From January to May, nocturnal formation occurred 2.5 times as often as daytime formation. Therefore it appears that in summer and autumn, nocturnal production was the major mechanism for aerosol formation in Tumbarumba. So far, nocturnal formation has not been reported to this degree at any other site around the world. Very limited nocturnal growth of cluster ions has been observed in Hyytiälä, too (Junninen et al., $2008^{2}$ ), and to a clearly larger degree in Abisko, northern Sweden (B. Svenningsson, personal communication). Why nocturnal formation is so much stronger in Tumbarumba is an open question and requires more thorough analysis that is beyond the scope of this paper.

\subsubsection{Meteorological variables}

Regardless of season, solar radiation was always higher during formation events than on other days (Fig. 4). This reflects the role of solar radiation in the formation of $\mathrm{OH}^{-}$and other atmospheric oxidants necessary in the particle formation process, although the difference was statistically significant only

\footnotetext{
${ }^{2}$ Junninen, H., Hulkkonen, M., Riipinen, I., Nieminen, T., Hirsikko, A., Suni, T., Boy, M., Lee, S.-H., Vana, M., Tammet, H., Kerminen, V.-M., and Kulmala, M.: Observations on nocturnal growth of atmospheric clusters, Atmos. Chem. Phys. Discuss., in revision, 2008.
} 
Table 1. Frequency of daytime and night-time formation events during July 2005-October 2006. Classification as in Fig. 2.

\begin{tabular}{llllllll}
\hline Month & Normal & Interrupted & Aitken & Non-events & Unclear days & Nocturnal events & Data days \\
\hline July-05 & 3 & 0 & 1 & 1 & 10 & 0 & 15 \\
Aug-05 & 4 & 0 & 0 & 1 & 2 & 0 & 8 \\
Sep-05 & 5 & 1 & 0 & 4 & 2 & 0 & 12 \\
Oct-05 & 8 & 0 & 2 & 2 & 12 & 0 & 24 \\
Nov-05 & 15 & 0 & 3 & 5 & 4 & 0 & 27 \\
Dec-05 & 17 & 0 & 3 & 1 & 5 & 0 & 26 \\
Jan-06 & 5 & 1 & 5 & 3 & 15 & 17 & 29 \\
Feb-06 & 7 & 0 & 6 & 0 & 10 & 19 & 23 \\
March-06 & 9 & 0 & 0 & 0 & 10 & 16 & 19 \\
April-06 & 6 & 0 & 0 & 0 & 19 & 18 & 25 \\
May-06 & 7 & 2 & 1 & 1 & 18 & 12 & 29 \\
June-06 & 15 & 1 & 0 & 0 & 13 & 16 & 29 \\
July-06 & 7 & 3 & 3 & 1 & 9 & 4 & 23 \\
Aug-06 & 16 & 0 & 0 & 2 & 8 & 0 & 15 \\
Sep-06 & 8 & 2 & 0 & 0 & 5 & 2 & 21 \\
Oct-06 & 16 & 0 & 2 & 0 & 3 & 8 & 351 \\
\hline Total & 148 & 10 & 26 & 21 & 145 & 112 & \\
\hline
\end{tabular}

in winter and spring (student t-test $p<0.005$ ). Temperature was higher on event days than on other days in spring, autumn, and winter, but lower in summertime. However, these differences were not statistically significant $(p>0.05)$. As observed in most previous studies (e.g. Hyvönen et al. 2005), relative humidity $(\mathrm{RH})$ was always lower on event days than on other days, although in summertime RH was so low that the difference between event days and other days was very small and not statistically significant; both were about $50 \%$. Formation events were typically absent during precipitation, but intermediate ions always appeared in the size range 2$8 \mathrm{~nm}$ for the duration of the rain in the same way as in Horrrak et al. (2005 and 2006). The suppressing effect of water vapour on particle formation in field conditions is a well known but poorly understood phenomenon.

\subsubsection{Growth rates}

Average growth rates (GR) for negatively/positively charged $1.3-3 \mathrm{~nm}$ particles were $2.89 / 2.68 \mathrm{nmh}^{-1}$, respectively; for 3-7 nm particles $4.26 / 4.03$, and for $7-20 \mathrm{~nm}$ particles $8.90 / 7.58 \mathrm{nmh}^{-1}$, respectively (Table 2). That average GR clearly increased with particle size (statistically highly significant differences, $p<0.005$ ) was expected because large particles usually occur later during the day when the concentration of condensable organic vapours is higher than in the morning: The emissions of terpenes from trees depend on temperature and/or photosynthesis. Another reason is that condensation is weaker on the smaller particles (Kelvin effect).

Comparing GR among different sites around the world is difficult because the number of formation events and the
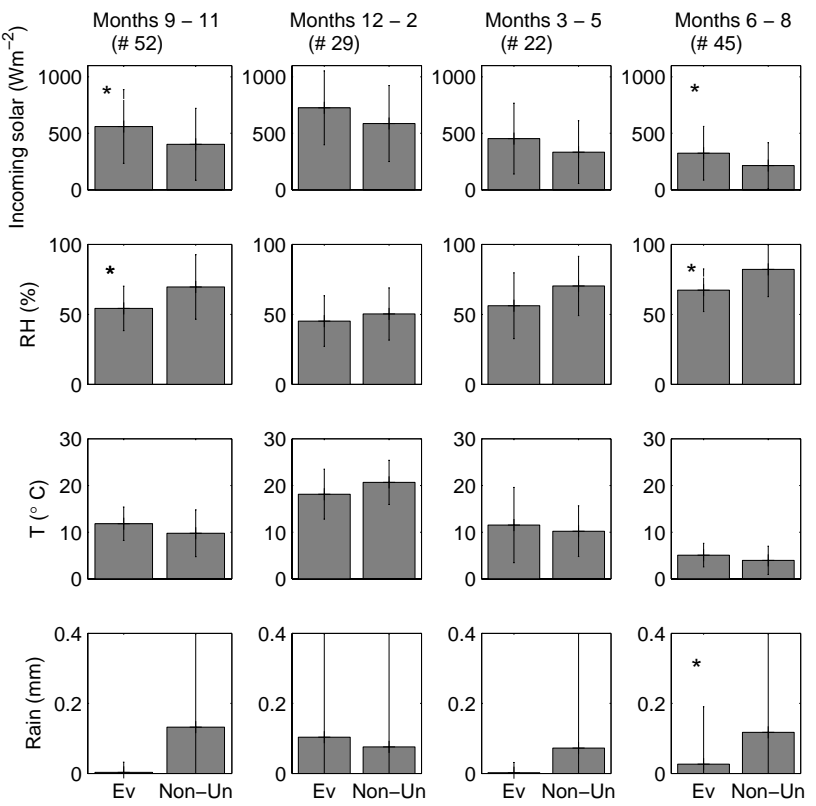

Fig. 4. Average meteorological variables on normal event days and on non-event/unclear days at 9-18. Each column corresponds to a season (months). The number of normal events per season is denoted as (\#) at the top of each column, and the error bars denote the standard deviation. The statistical difference of the averages was tested using student's t-test; a statistically highly significant difference $(p<0.005)$ is labelled with *.

size range used for GR determination varies. The GR in Tumbarumba are well within the range reported in Kulmala et al. (2004) but the only fully comparable observations at the moment are from a boreal forest in Hyytiälä, southern 
Table 2. Average growth rates $\left(\mathrm{nmh}^{-1}\right)$ ( \pm standard deviation) for negative and positive ions of three size classes. The difference in growth rates among different size classes was statistically highly significant (t-test; $p<0.005$ ) but the average growth rates of positive and negative ions within any one size class were not statistically different.

\begin{tabular}{llll}
\hline & $1.3-3 \mathrm{~nm}$ & $3-7 \mathrm{~nm}$ & $7-20 \mathrm{~nm}$ \\
\hline- & $2.89( \pm 2.93)$ & $4.26( \pm 4.08)$ & $8.90( \pm 8.23)$ \\
+ & $2.68 \pm(2.46)$ & $4.03( \pm 4.20)$ & $7.58( \pm 7.98)$ \\
\hline
\end{tabular}

Finland, where the average GR for 3-7 nm particles were 2-4 nmh ${ }^{-1}$, almost the same as in Tumbarumba, but where the $1.3-3 \mathrm{~nm}$ and $7-20 \mathrm{~nm}$ particles grew slower at $<2$ and $4-5 \mathrm{nmh}^{-1}$, respectively (Hirsikko et al., 2005); for large particles, the GR in Tumbarumba were approximately twice as large as in Hyytiälä. In the only other terrestrial measurements made in non-urban Australia (within the Kakadu National Park in tropical Northern Territory), Thomas et al. $\left(2008^{1}\right)$ report one value, $5 \mathrm{nmh}^{-1}$, for $10-20 \mathrm{~nm}$ particles in Jabiru Town, the least remote location of the three studied. In Jabiru Town, the formation events were quick and short (only a couple of hours), and the authors mention that at Gimbat, the most remote bushland site, the GR were lower and the events took several hours. They attributed this to the lower background concentration of pre-existing aerosol at Gimbat. Indeed, if pre-existing aerosol is abundant, GR must be large in order to compensate for the large coagulation sink that scavenges the newly formed particles (Kulmala et al., 2004). In a cleaner area, even particles with smaller GR can reach detectable sizes. In Tumbarumba, the background ultrafine aerosol concentration was about half compared to that in Hyytiälä (3.2.1). Had the source strength of condensable vapours been equal at both sites, this smaller coagulation sink should then have led to slower GR in Tumbarumba than in Hyytiälä. However, we observed the opposite, which suggests that the source of condensing vapours was stronger in Tumbarumba than in Hyytiälä, enabling the particles to grow faster.

The GR for large ions was highest in summer from October/November to May (Fig. 5). This pattern is typical around the world although in our study, the difference among seasons was not statistically significant. The time series measured in Tumbarumba is most likely too short. The summer maximum is consistent with organic vapours forming a large part of the condensing matter as their concentrations should be highest in summertime (Kulmala et al., 2004; Dal Maso et al., 2007). No clear seasonal pattern was evident for intermediate or cluster ions (Fig. 5). This suggests that substances other than organic vapours, such as sulphuric acid, have an important role in the condensational growth of these particles.

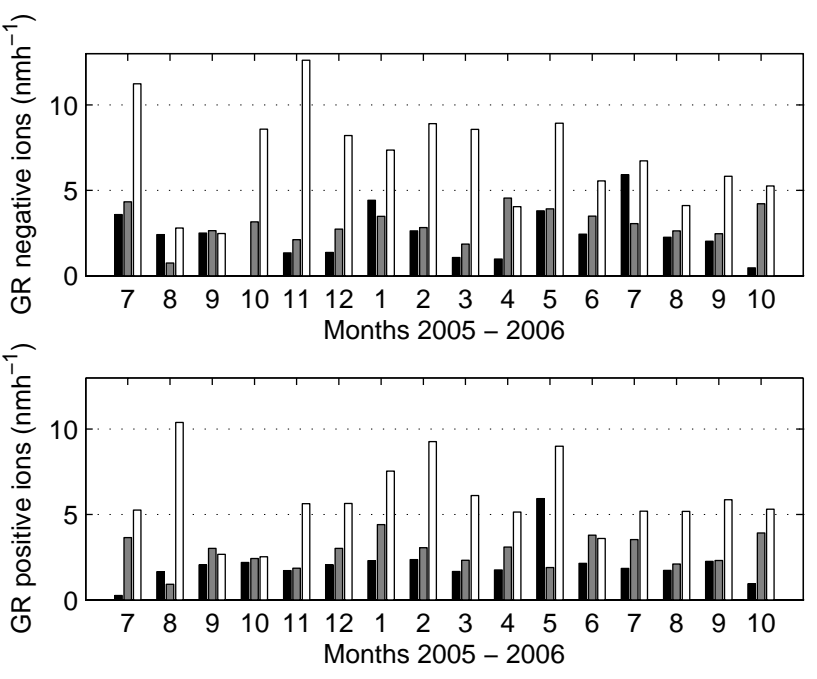

Fig. 5. Monthly GR for three size classes of ions. Top - negative ions, bottom - positive ions. Black: $1.3-3 \mathrm{~nm}$; grey: $3-7 \mathrm{~nm}$; white: $7-20 \mathrm{~nm}$.
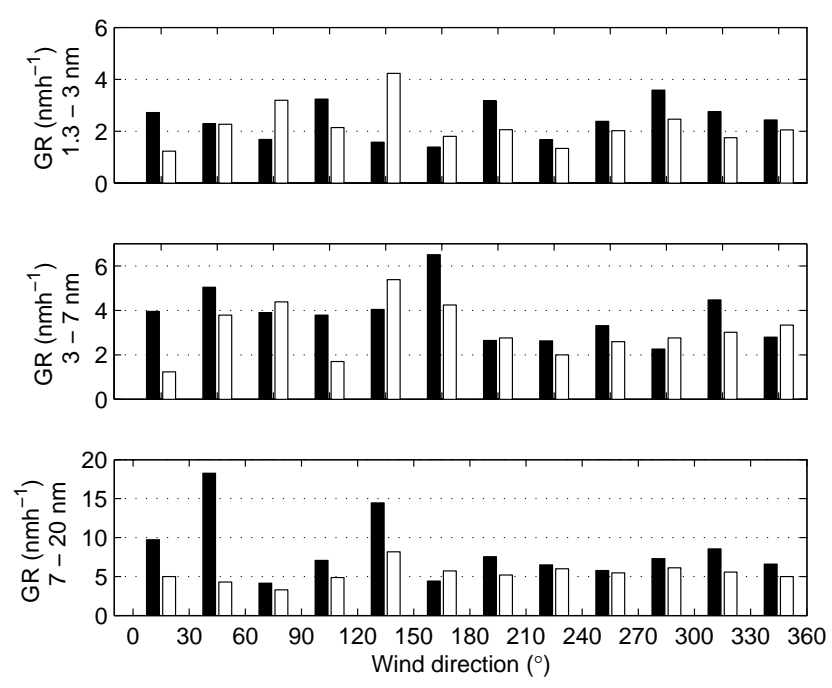

Fig. 6. GR as a function of wind direction for the three size classes during July 2005 to October 2006. Black - negative, white - positive.

The differences in the growth rates that occurred in easterly $\left(0-180^{\circ}\right)$ and westerly $\left(180-360^{\circ}\right)$ local winds (Fig. 6) were not statistically different. However, when we narrowed the wind direction windows to half $\left(45-135^{\circ}\right.$ and $225-$ $315^{\circ}$ ) to better represent the Eucalyptus forests in the eastern mountains and the agricultural fields and grasslands in the western lowlands, we observed an almost statistically significant difference (significant with $p<0.1$ ) with the GR for large ions higher for easterly than westerly winds. This suggests that the source of some condensable vapours was stronger in the dense, tall Eucalypt forest than in the agricultural fields. Indeed, the far larger biomass of the tall open Eucalypt forests should produce larger amounts of organic 
vapours than the agricultural lowlands. However, our dataset of 16 months is too short for statistically reliable analysis of wind-direction and seasonal dependencies.

\subsection{Ion and aerosol concentrations}

\subsubsection{Ultrafine particle concentration}

The average concentration of ultrafine particles $(>14 \mathrm{~nm})$ in Tumbarumba was about $1200 \mathrm{~cm}^{-3}$ with a median of $900 \mathrm{~cm}^{-3}$ (not shown). This was lower than in Kakadu (Thomas et al., 2008 ${ }^{1}$ ): The average background concentrations of $8-400 \mathrm{~nm}$ particles there were consistently around $2000 \mathrm{~cm}^{-3}$, similarly to Hyytiälä, where for 3-1000 nm particles the average is around 2300 and the median around $1850 \mathrm{~cm}^{-3}$ (M. Dal Maso, personal communication). The difference in the lower size limit of these measurements is not very significant except during a formation event; usually the size classes between 3 and $14 \mathrm{~nm}$ are more or less empty. In clean rural areas along a train track from Moscow to Vladivostok, concentrations of 3-950 nm particles were higher at 4300 (average) and 2600 (median) $\mathrm{cm}^{-3}$ (Vartiainen et al., 2007). Compared to Finland and a large part of Russia (such as close to the Baykal-Amur railway), Australia is very sparsely populated and cities are mostly spread over a large area. Night-time concentrations even in cities such as in central Brisbane can sometimes be as low as the Kakadu background, $2000 \mathrm{~cm}^{-3}$ (L. Morawska, personal communication). The background concentrations in the forested mountains of Tumbarumba appear therefore to represent very clean air.

\subsubsection{Ion concentrations}

Observations of ion concentrations and dynamics in the field are essential for better understanding of ion and new-particle production and growth. The relative concentrations of positive and negative ions vary around the world but the underlying reasons are still largely unknown. Theoretically, ioninduced nucleation especially with negative ions requires less energy than homogeneous nucleation (Kusaka et al., 1995; Lovejoy et al., 2004: Laakso et al., 2007). In Tumbarumba, positive and negative cluster ion concentrations were approximately equal until spring 2006, after which negative concentrations increased until they were approximately 1.4-fold compared to the positive ones (Fig. 7a and b). A clear imbalance was also observed in Russia with more negative than positive cluster ions (Vartiainen et al., 2007) and in the Alps in Jungfraujoch with more positive than negative ions (Vana et al., 2006). In Tumbarumba, the same applied also to large ions, except that in the beginning of the measuring period, positive ions were more abundant than negative (Fig. 7e and f). In Russia, large positive ion concentration similarly exceeded that of negative but only slightly (Vartiainen et al.,
2007). Intermediate ions in Tumbarumba were usually in balance (Fig. 7c and d).

Typically, the daytime concentrations of intermediate ions reflect daytime formation events. However, in March and April 2006 also the nocturnal type extended partly to daytime in the morning and early evening and, together, these daytime and nocturnal formation events produced the highest daytime concentrations of the whole measuring period (Fig. 7c). The night-time concentrations of the intermediate ions (Fig. 7d) reflected the nocturnal formation and its very strong seasonal variability. The night-time concentrations were often higher than daytime concentrations but this does not necessarily indicate that aerosol formation was stronger at night than in daytime: At night, the particles accumulate in a shallower boundary layer than in daytime.

Intermediate ions appeared during formation events but also during rain. However, no growth was evident during these rain events and the sizes of the appearing intermediate particles were small, only $2-8 \mathrm{~nm}$. This is in agreement with earlier findings in Hyytiälä (Hõrrak et al., 2006; Hirsikko et al., 2007a). The concentrations of negative ions usually increased more than those of positive ions: The strong peaks up to 5 -fold $-/+$ ratio were mainly due to rain events (Fig. 7c and d).

On average, concentrations of negative (positive) cluster ions were about $2400(1700) \mathrm{cm}^{-3}$ which is much higher than the $600-800 \mathrm{~cm}^{-3}$ in Hyytiälä (Hirsikko et al., 2005) or the $300(600) \mathrm{cm}^{-3}$ for negative (positive) ions at alpine Jungfraujoch (Vana et al., 2006). To our knowledge, similarly high concentrations have been observed only in Abisko, northern Sweden (B. Svenningsson, personal communication). The average concentrations in Tumbarumba were even higher than the $\sim 1300(\sim 600) \mathrm{cm}^{-3}$ found in Russia. The maximum concentrations there were correlated with radon concentrations high enough to produce up to 30 ion pairs $\mathrm{cm}^{-3} \mathrm{~s}^{-1}$ (Vartiainen et al., 2007). The very high concentrations of cluster ions in Tumbarumba imply that the ion production rate was as much as 50-100 ion pairs $\mathrm{cm}^{-3} \mathrm{~s}^{-1}$, which is 5-20 times more than the values obtained in Hyytiälä (Hirsikko et al., 2007b). This would indicate the presence of a very efficient ion source such as high efflux of radon from the Tumbarumba soil. Accumulation of atmospheric radon from the ground source could also be linked to the very strong nocturnal ion production in summer and autumn. Another indication towards the important role played by radon is that the highest ion concentrations in Tumbarumba usually took place in the early morning which is frequently when inversions and accumulation of radon occur. Indeed, two days of measurements revealed very high concentration of radon in Tumbarumba that ranged from 9 to $102 \mathrm{Bqm}^{-3}$ on the ground (not shown). In Hyytiälä, typical radon concentrations at a few metres above the ground are only $1-2 \mathrm{Bqm}^{-3}$ (Hirsikko et al., 2007b).

Median concentrations of small intermediate ions (1.6$6.3 \mathrm{~nm}$ ) in Tumbarumba were about $94 \mathrm{~cm}^{-3}$ for both 


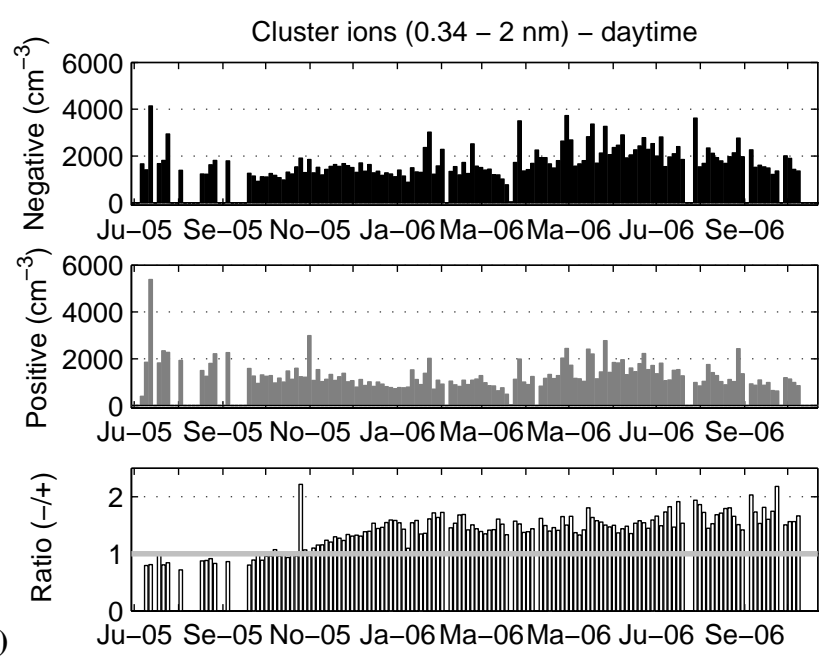

(b)
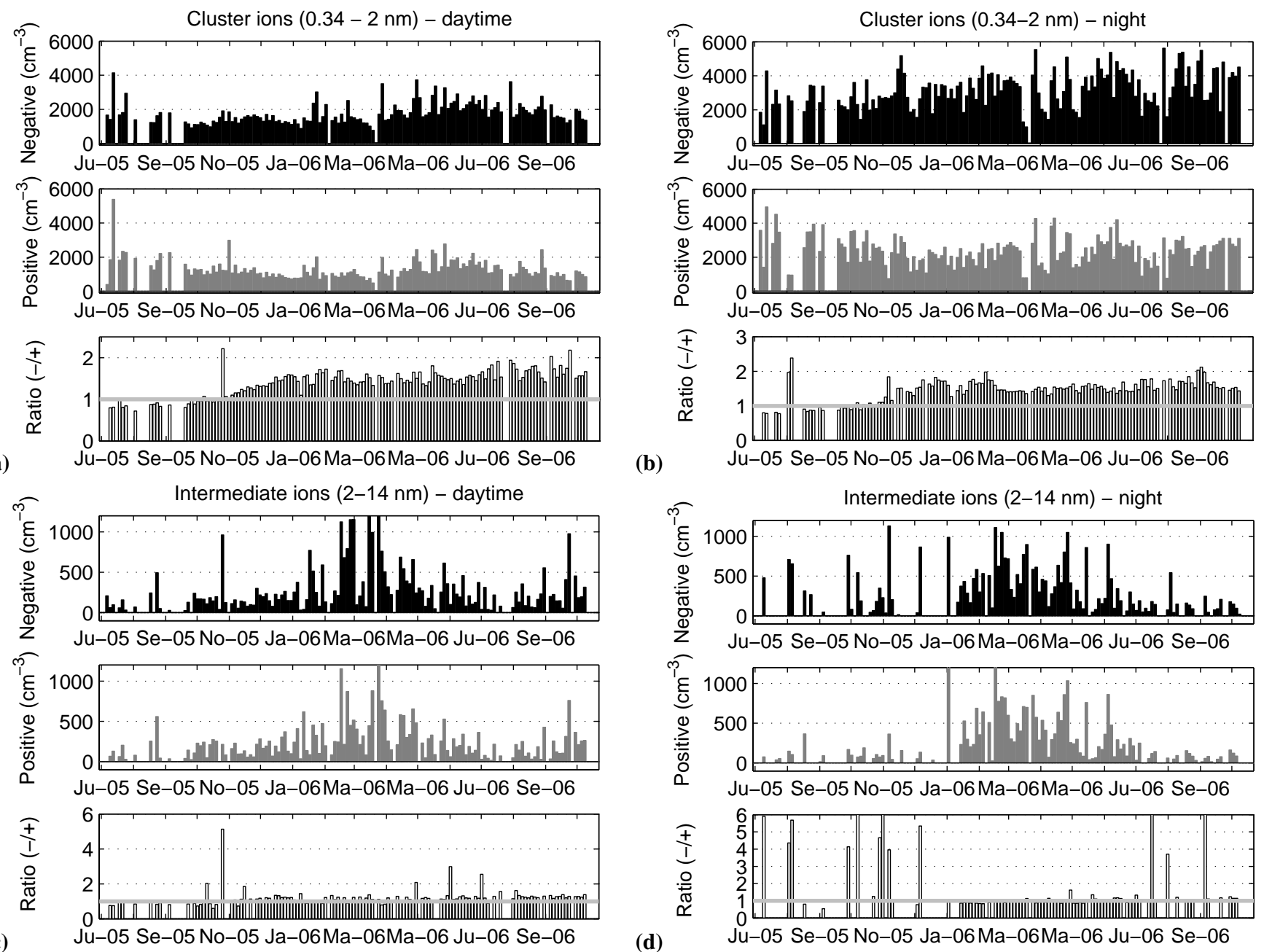

(c) Ju-05 Se-05 No-05 Ja-06 Ma-06Ma-06 Ju-06 Se-06

(d)

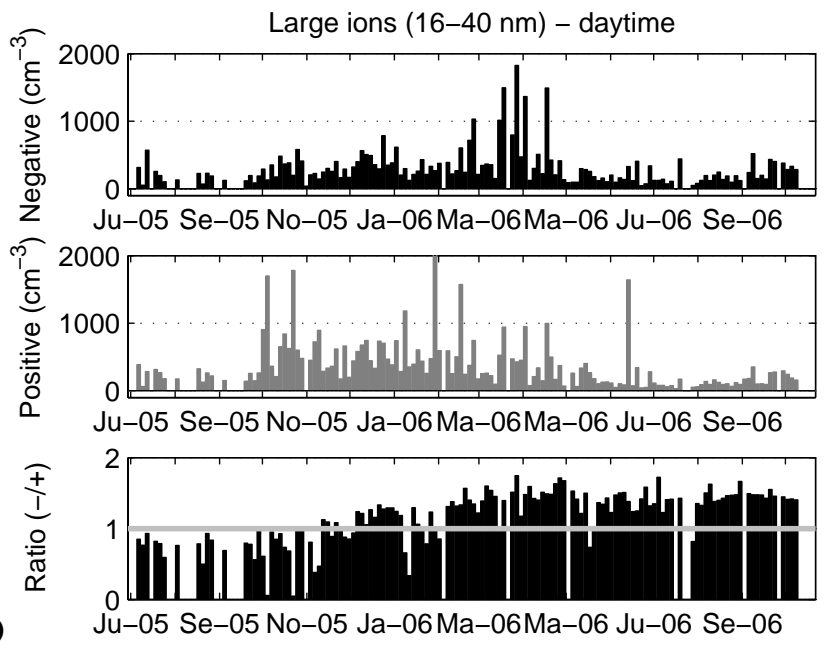

(a)

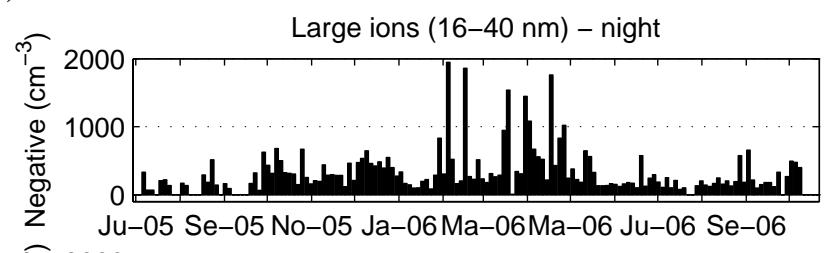

क्षे


Fig. 7. 3-day median ion concentrations (black - negative, grey - positive) and ion ratio (-/+) for cluster (top), intermediate (middle), and large ions (bottom) during July 2005 - October 2006. Left column - daytime, right column - night time. 
polarities. This is roughly the same as in Hyytiälä where intermediate ions of the same size remained usually below $200 \mathrm{~cm}^{-3}$ (Hirsikko et al., 2005). Median concentrations of large ions $(16-40 \mathrm{~nm})$ were $220-240 \mathrm{~cm}^{-3}$ for both polarities in Tumbarumba.

Comparing particle concentrations in the high daytime boundary layer (DBL) and in the shallower nocturnal boundary layer (NBL) can give some indication as to when and where particles of different sizes are formed. In Tumbarumba, median concentrations of cluster ions were $80 \%$ higher at night than in daytime (Table 3). This, combined with the short lifetime of cluster ions $(<2-3 \mathrm{~min})$, suggests that the clusters are produced both within DBL and NBL but because DBL is higher and better mixed than NBL, cluster concentrations are diluted during daytime. On the contrary, no clear difference between day and night concentrations was evident for large ions (Table 3). This means that they must be produced mainly in daytime or, theoretically, above NBL. Nothing produced above NBL can be seen inside it because the inversion prevents mixing between NBL and the residual layer above it.

These results support the idea that the main producer of cluster ions is radon efflux from the ground. The sources of large ions within the boundary layer are most likely daytime and night-time aerosol formation and long-range transport from pollution sources. Assuming that the sinks of the large ions stay the same in daytime and night time, the sum of these sources appears to be stronger in daytime than in night time - if this was not the case, accumulation in the shallower NBL would lead to a similar diurnal pattern as for the cluster ions.

\section{Conclusions}

The Eucalypt forest in Tumbarumba was a very active source of new aerosol particles not only in daytime but in summer and autumn also in night time. On average, a daytime formation event took place on $52 \%$ of days with acceptable data during the measuring period. This is $2-3$ times as often as in the Nordic boreal zone. Furthermore, the ratio of banana-type events to non-events was 6-18 times higher in Tumbarumba than in the North. The particularly clean air in Tumbarumba and the lack of a cold and dark winter are likely reasons for this difference. The most conducive conditions for formation events were dry, sunny days. The growth rates for large ions were highest when the air was coming from the native forest which suggests that the Eucalypts were a strong source of condensable vapours. The growth rates for large ions were highest in summer although our time series was probably too short for this seasonal maximum to be statistically significant. Similar summer maxima for the growth rates of large ions have been observed in other studies as well which suggests that organic vapours, side products of photosynthesis, form a large part of the condensing matter. That
Table 3. Median ratio of night-time to daytime concentrations of cluster ions (0.34-2 nm) and large ions (16-40 nm).

\begin{tabular}{lll}
\hline & $0.34-2 \mathrm{~nm}$ & $16-40 \mathrm{~nm}$ \\
\hline$-\quad 1.9$ & 1.1 \\
$+\quad 1.8$ & 0.9 \\
\hline
\end{tabular}

no clear seasonal pattern was evident in the growth rates of intermediate or cluster ions indicates that other substances such as sulphuric acid could have an important role in the condensational growth of these particles.

We observed higher average concentrations of cluster ions than reported for most other sites around the world. One possible reason could be strong radon efflux from the ground. Comparison between night-time and daytime concentrations supported the view that cluster ions are produced close to the surface within the boundary layer also at night but that large ions are mostly produced in daytime. A previously unreported phenomenon, nocturnal aerosol production, was observed from summer to early winter. It appeared on $32 \%$ of the analysed nights and almost entirely within six months from January to June in 2006. From January to May, it occurred 2.5 times as often as daytime formation; for this part of the year, nocturnal production was the major mechanism for aerosol formation in Tumbarumba. The nucleation and particle growth mechanisms behind this surprising phenomenon are unclear and require more study.

Acknowledgements. This work was supported by the Academy of Finland, Maj and Tor Nessling Foundation, and the Centennial Foundation of Helsingin Sanomat. Support for the Tumbarumba flux tower facility and its operation was provided both by CSIRO and the Australian Greenhouse Office's Australian Climate Change Science Program. Funding for the aerosol program was also provided by the New South Wales Environmental Trusts.

Edited by: A. Laaksonen

\section{References}

Andronache, C., Grönholm, T., Laakso, L., Phillips, V., and Venäläinen, A.: Scavenging of ultrafine particles by rainfall at a boreal site: observations and model estimations, Atmos. Chem. Phys., 6, 4739-4754, 2006,

http://www.atmos-chem-phys.net/6/4739/2006/.

Arnold, F., Krankowsky, D., and Marien, K. H.: First mass spectrometric measurements of positive ions in the stratosphere, Nature, 267, 30-32, 1977.

Bates, T .S., Quinn, P. K., Covert, D. S., Coffman, D. J., Johnson, J. E., and Wiedensohler, A.: Aerosol physical properties and processes in the lower marine boundary layer: a comparison of shipboard sub-micron data from ACE-1 and ACE-2, Tellus, 52B, 258-272, 2000. 
Dal Maso, M., Kulmala, M., Riipinen, I., Wagner, R., Hussein, T, Aalto, P. P., and Lehtinen, K. E. J.: Formation and growth rates of fresh atmospheric aerosols: eight years of aerosol size distribution data from SMEARII, Hyytiälä, Finland, Boreal Env. Res., 10, 323-336, 2005.

Dal Maso, M., Sogacheva, L., Aalto, P. P., Riipinen, I., Komppula, M., Tunved, P., Korhonen, L., Suur-Uski, V., Hirsikko, A., Kurtén, T., Kerminen, V.-M., Lihavainen, H., Viisanen, Y., Hansson, H.-C., and Kulmala, M.: Aerosol size distribution measurements at four Nordic field stations: identification, analysis and trajectory analysis of new particle formation bursts, Tellus B, 59(3), 350-361, doi:10.1111/j.1600-0889.2007.00267.x, 2007.

Eichkorn, S., Wilhelm, S., Aufmhoff, H., Wohlfrom, K. H., and Arnold, F.: Cosmic ray induced, aerosol-formation: First observational evidence from aircraft-based ion mass spectrometer measurements in the upper troposphere, Geophys. Res. Lett., 29(14), 1698, doi:10.1029/2002GL015044, 2002.

Eisele, F. L., Lovejoy, E. R., Kosciuch, E., Moore, K. F., Mauldin III, R. L., Smith, J. N., McMurry, P. H., and Iida, K.: Negative atmospheric ions and their potential role in ion-induced nucleation, J. Geophys. Res., 111, D04305, doi:10.1029/2005JD006568, 2006.

Generoso, S., Breon, F. M., Balkanski, Y., Boucher, O., and Schulz, M.: Improving the seasonal cycle and interannual variations of biomass burning aerosol sources, Atmos. Chem. Phys., 3, 12111222, 2003 http://www.atmos-chem-phys.net/3/1211/2003/.

Gras, J. L., Jensen, J. B., Okada, K., Ikegami, M., Zaizen, Y., and Makino, Y.: Some optical properties of smoke aerosol in Indonesia and tropical Australia, Geophys. Res. Lett., 26(10), 13931396, 1999.

Gras, J. L.: Southern Hemisphere tropospheric aerosol microphysics, J. Geophys. Res., 96(D3), 5345-5356, 1991.

Hirsikko, A., Bergman, T., Laakso, L., Dal Maso, M., Riipinen, I., Hõrrak, U., and Kulmala, M.: Identification and classification of the formation of intermediate ions measured in boreal forest, Atmos. Chem. Phys., 7, 201-210, 2007a.

Hirsikko, A., Laakso, L., Hõrrak, U., Aalto, P. P, Kerminen, V.M., and Kulmala, M.: Annual and size dependent variation of growth rates and ion concentrations in boreal forest, Boreal Env. Res., 10, 357-369, 2005.

Hirsikko, A., Paatero, J., Hatakka, J., and Kulmala, M.: The 222Rn activity concentration, external radiation dose rate and air ion production rate in a boreal forest in Finland between March 2000 and June 2006, Boreal Env. Res., 12, 265-278, 2007 b.

Hõrrak, U.: Air ion mobility spectrum at a rural area. $\mathrm{PhD}$ thesis, University of Tartu, 158 pp., 2001.

Hõrrak, U., Salm, J., and Tammet, H.: Bursts of intermediate ions in atmospheric air, J. Geophys. Res., 103, 13 909-13 915, 1998.

Hõrrak, U., Tammet, H., Aalto, P. P., Vana, M., Hirsikko, A., Laakso, L. and Kulmala, M.: Formation of charged nanometer aerosol particles associated with rainfall, Abstracts of the European Aerosol Conference 2005, Ghent, edited by: Maenhaut, W., p. 606, 2005.

Hõrrak, U., Tammet. H., Aalto, P. P., Vana, M., Hirsikko, A., Laakso, L. and Kulmala, M.: Formation of charged nanometer aerosol particles associated with rainfall: Atmospheric measurements and lab experiment, Proceedings of BACCI, NECC and FCoE activities 2005, Report Series in Aerosol Sciences, 81A,
180-185, 2006.

Hyvönen, S., Junninen, H., Laakso, L., Dal Maso, M., Grönholm, T., Bonn, B., Keronen, P., Aalto, P., Hiltunen, V., Pohja, T., Launiainen, S., Hari, P., Mannila, H., and Kulmala, M.: A look at aerosol formation using data mining techniques, Atmos. Chem. Phys., 5, 3345-3356, 2005,

http://www.atmos-chem-phys.net/5/3345/2005/.

Israël, H.: Atmospheric electricity, vol. 1: Fundamentals, conductivity, ions, Israel Program for Scientific Translations, Jerusalem, 1970.

Jimi, S. I., Gras, J. L., Siems, S. T., and Krummel, P. B.: Nanoparticles at Cape Grim, Tasmania, in: Cape Grim Baseline Air Pollution Station Annual Science Meeting: abstracts, CSIRO Atmospheric Research, edited by: Cainey, J. M. and Derek, N., Aspendale, Vic.: CSIRO Atmospheric Research; Bureau of Meteorology, p. 24, 2003.

Johnson, G. R., Ristovski, Z. D., D’Anna, B., and Morawska, L.: Hygroscopic behavior of partially volatilized coastal marine aerosols using the volatilization and humidification tandem differential mobility analyzer technique, J. Geophys. Res., 110, D20203, doi:10.1029/2004JD005657, 2005.

Kanawade, V. and Tripathi, S. N.: Evidence for the role of ion-induced particle formation during an atmospheric nucleation event observed in Tropospheric Ozone Production about the Spring Equinox (TOPSE), J. Geophys. Res., 111, D02209, doi:10.1029/2005JD006366, 2006.

Kazil, J. and Lovejoy, E. R.: Tropospheric ionization and aerosol production: A model study, J. Geophys. Res., 109, D19206, doi:10.1029/2004JD004852, 2004.

Kerminen, V.-M., Lihavainen, H., Komppula, M., Viisanen, Y., and Kulmala, M.: Direct observational evidence linking atmospheric aerosol formation and cloud droplet activation, Geophys. Res. Lett., 32, L14803, doi:10.1029/2005GL023130, 2005.

Keywood, M. D., Ayers, G. P., Gras, J. L., and Gillett, R. W.: Size distribution and sources of aerosol in Launceston, Australia, during winter 1997, Air Waste Manage. Assoc., 50, 418-427, 2000.

Kulmala, M., Vehkamäki, H., Petäjä, T., Dal Maso, M., Lauri, A., Kerminen, V.-M., Birmili, W., and McMurry, P. H.: Formation and growth rates of ultrafine atmospheric particles: A review of observations, J. Aerosol Sci., 35, 143-176, 2004.

Kusaka, I., Wang, Z.-G., and Seinfeld, J. H.: Ion-induced nucleation, II, Polarizable multipolar molecules, J. Chem. Phys., 103, 8993-9009, 1995.

Laakso, L., Gagné, S., Petäjä, T., Hirsikko, A., Aalto, P. P., Kulmala, M., and Kerminen, V.-M.: Detecting charging state of ultra-fine particles: instrumental development and ambient measurements, Atmos. Chem. Phys., 7, 1333-1345, 2007, http://www.atmos-chem-phys.net/7/1333/2007/.

Laakso, L., Lehtinen, K., and Kulmala, M.: The effect of condensation rate enhancement factor on 3-nm particle formation in binary ion-induced and homogeneous nucleation, J. Geophys. Res., 108(D18), 4574, doi:10.1029/2003JD003432, 2003.

Laakso, L., Mäkelä, J. M., Pirjola, L., and Kulmala, M.: Model studies on ion-induced nucleation in the atmosphere, J. Geophys. Res., 108(D20), 4427, doi:10.1029/2002JD002140, 2002.

Laaksonen, A., Hamed, A., Joutsensaari, J., Hiltunen, L., Cavalli, F., Junkermann, W., Asmi, A., Fuzzi, S., and Facchini, M.C.: Cloud condensation nuclei production from nucleation events at a highly polluted region, Geophys. Res. Lett., 32, L06812, 
doi:10.1029/2004GL022092, 2005.

Lee, S.-H., Reeves, J. M., Wilson, J. C., Hunton, D. E.,. Viggiano, A. A, Miller, T. M., Ballenthin, J. O., and Lait, L. R.: Particle formation by ion nucleation in the upper troposphere and lower stratosphere, Science, 301, 1886-1889, 2003.

Leuning, R., Cleugh, H. A., Zegelin, S. J., and Hughes, D.: Carbon and water fluxes over a temperate Eucalyptus forest and a tropical wet/dry savanna in Australia: measurements and comparison with MODIS remote sensing estimates, Agric. For. Meteorol., 129, 151-173, 2005.

Lovejoy, E. R., Curtius, J., and Froyd, K. D. Atmospheric ioninduced nucleation of sulfuric acid and water, J. Geophys. Res., 109, D08204, doi:10.1029/2003JD004460, 2004.

Mirme, A., Tamm, E., Mordas, G., Vana, M., Uin, J., Mirme, S., Bernotas, T., Laakso, L., Hirsikko, A., and Kulmala, M.: A widerange multi-channel Air Ion Spectrometer, Boreal Env. Res., 12, 247-264, 2007.

Pruppacher, H. R. and Klett, J. D.: Microphysics of clouds and precipitation, second revised and enlarged edition with an introduction to cloud chemistry and cloud electricity, Springer, 976 pp., 1997.

Simoneit, B. R. T., Crisp, P. T., Mazurek, M. A., and Standley, L. J.: Composition of extractable organic matter of aerosols from the Blue Mountains and Southeast coast of Australia, Environment International, 17, 405-419, 1991.

Spracklen, D. V., Carslaw, K. S., Kulmala, M., Kerminen, V.-M., Mann, G. W., and Sihto, S.-L.: The contribution of boundary layer nucleation events to total particle concentrations on regional and global scales, Atmos. Chem. Phys., 6, 5631-5648, 2006 , http://www.atmos-chem-phys.net/6/5631/2006/.

Tammet, H., Salm, J., and Iher, H.: Observation of condensation on small air ions in the atmosphere, Lect. Notes Phys., 309, 239$240,1988$.
Turco, R. P., Zhao, J.-X., and Yu, F.: A new source of tropospheric aerosols: Ion-ion recombination, Geophys. Res. Lett., 25, 635638, 1998.

Vana, M., Hirsikko, A., Tamm, E., Aalto, P. P., Kulmala, M., Verheggen, B., Cozic, J., Weingartner, E., and Baltensperger, U.: Characteristics of air ions and aerosol particles at the high-alpine research station Jungfraujoch, Proc. of the International Aerosol Conference, St. Paul, Minnesota, US, 10-15 September, 1427, 2006.

Vartiainen, E., Kulmala, M., Ehn, M., Hirsikko, A., Junninen, H., Petäjä, T., Sogacheva, L., Kuokka, S., Hillamo, R., Skorokhod, A., Belikov, I., Elansky, N., and Kerminen, V.-M.: Ion and particle number concentrations and size distributions along the TransSiberian railroad, Boreal Env. Res., 12, 375-396, 2007.

Yu, F. and Turco, R. P.: From molecular clusters to nanoparticles: Role of ambient ionization in tropospheric aerosol formation, J. Geophys. Res., 106, 4797-4814, 2001.

Yu, F.: From molecular clusters to nanoparticles: Secondgeneration ion-mediated nucleation model, Atmos. Chem. Phys., 6, 5193-5211, 2006, http://www.atmos-chem-phys.net/6/5193/2006/.

Zaizen, Y., Ikegami, M., Tsutsumi, Y., Makino, Y., Okada, K., Jensen, J., and Gras, J. L.: Number concentration and size distribution of aerosol particles in the middle troposphere over the western Pacific Ocean, Atmos. Env., 30, 1755-1762, 1996. 